IZA DP No. 6147

Occupational Adjustment of Immigrants

Aslan Zorlu

November 2011 


\title{
Occupational Adjustment of Immigrants
}

\author{
Aslan Zorlu \\ University of Amsterdam \\ and IZA
}

\section{Discussion Paper No. 6147 \\ November 2011}

\author{
IZA \\ P.O. Box 7240 \\ 53072 Bonn \\ Germany \\ Phone: +49-228-3894-0 \\ Fax: +49-228-3894-180 \\ E-mail: iza@iza.org
}

\begin{abstract}
Any opinions expressed here are those of the author(s) and not those of IZA. Research published in this series may include views on policy, but the institute itself takes no institutional policy positions.

The Institute for the Study of Labor (IZA) in Bonn is a local and virtual international research center and a place of communication between science, politics and business. IZA is an independent nonprofit organization supported by Deutsche Post Foundation. The center is associated with the University of Bonn and offers a stimulating research environment through its international network, workshops and conferences, data service, project support, research visits and doctoral program. IZA engages in (i) original and internationally competitive research in all fields of labor economics, (ii) development of policy concepts, and (iii) dissemination of research results and concepts to the interested public.
\end{abstract}

IZA Discussion Papers often represent preliminary work and are circulated to encourage discussion. Citation of such a paper should account for its provisional character. A revised version may be available directly from the author. 
IZA Discussion Paper No. 6147

November 2011

\section{ABSTRACT}

\section{Occupational Adjustment of Immigrants ${ }^{*}$}

This paper examines the speed of the occupational adjustment of immigrants using Labour Force Surveys 2004 and 2005 from Statistics Netherlands. The analysis provides new evidence that immigrants start with jobs at the lower levels of skill distribution. Their occupational achievement improves significantly with the duration of residence. The extent of this initial disadvantage and the rate of adjustment vary across immigrant groups according to the transferability of skills associated with their cultural and linguistic distance from Dutch society as predicted by the theory of immigrant occupational mobility. Most notably, Turks and Moroccans face the greatest initial dip and achieve the highest rate of adjustment while the opposite holds for Caribbean and Western immigrants. Our results are robust to three alternative measures of occupational status.

JEL Classification: J15, J24

Keywords: ethnic minorities, quality of jobs

Corresponding author:

Aslan Zorlu

University of Amsterdam

Faculty of Social and Behavioural Sciences

Nieuwe Prinsengracht 130

1018 VZ Amsterdam

The Netherlands

E-mail: A.Zorlu@uva.nl

\footnotetext{
* The research was based on collaboration with Statistics Netherlands. I am grateful to Henk-Jan Dirven, Frank van Tubergen, participants of 8th IZA Annual Migration Meeting (AM²), 12-15 May 2011 in Washington for valuable comments, and two anonymous reviewers of this journal.
} 


\section{Introduction}

Over the past three decades, a growing number of studies has examined the labour market adjustment of immigrants. Many of them have used conventional human capital earnings functions as a single labour-market outcome (Chiswick 1978; Chiswick and Miller, 2009; Duleep and Regets, 1999; Friedberg 2000) In fact, they assume a nearly perfect correlation between earnings and occupation. Such an assumption possibly arises from similarities in the underlying determinants of both earnings and occupational attainment, such as education and risk behaviour. However, human capital is primarily occupation specific and occupational choice serves as an intervening mechanism for earnings (Kambourov and Manovskii 2009). Individuals tend to accumulate more occupational experience and try to avoid switching their occupations because changing occupation would lead to earnings loss.

The correlation between earnings and occupations is only likely to be strong in flexible labour markets where occupational mobility is high enough. For highly-regulated labour markets like the Dutch, mobility across occupations is not high. There are usually well-defined basic requirements for occupations, such as a completed formal education, experience, and countryspecific capital usually referring to communication skills, social norms and ability in the Dutch language. In addition, there may be further invisible barriers for immigrants in the Netherlands labour market, which is characterized by historically strongly-developed institutions. Immigrants often lack these basic requirements when they arrive in the Netherlands. In such an environment, earnings may be a poor measure of labour-market outcome for the Netherlands where immigrants are frequently unemployed and the welfare system is generous.

Recent literature has emphasized the importance of occupations in determining social and economic well-being and studied occupational mobility of immigrants (Chiswick, Lee and Miller 2005; Chiswick and Miller, 2008b; Akresh 2006; Rooth and Ekberg 2006; Kanas and van Tubergen, 2009). These studies have typically used an index of occupations such as the International Socio-Economic Index (ISEI). The tenor of the results from these studies is that occupational adjustment of immigrants follows a U-shaped pattern of occupational mobility from the last job in the origin and subsequent jobs in the host country: occupational status of immigrants declines after immigration sharply and subsequently increases with duration of residence in the host country as they acquire more host-country-specific capital.

The initial disadvantage has been mainly attributed to the low international transferability of foreign human capital and the lack of country-specific human capital in terms of poor proficiency in the local language (Chiswick and Miller 2009; Friedberg 2000). Empirical studies provide solid evidence of a lower return on foreign schooling and experience. Improvement in the position of immigrants critically depends on their post-immigration investment in host-country-specific capital which is positively correlated with their human capital endowment acquired abroad (Duleep and Regets, 1999; Van Tubergen and van de Werfhorst, 2007).

The studies on occupational attainment of immigrants typically rely on small cross-sectional surveys and seldom on a longitudinal survey because longitudinal data on immigrants are scarce. Only the study of Chiswick, Lee and Miller (2005) uses a longitudinal survey from Australia. Although these surveys include detailed information about education and occupation in both origin country and destination country, the small sample size restricts opportunities to investigate differences in the speed and pattern of adjustment across separate countries of origin. This paper uses the Netherlands Labour Force Survey (LFS) which is the best available data for our purposes because it includes detailed information about education 
and occupation, since longitudinal register data for the Netherlands do not include these important variables. The LFS has however no information about duration of residence. Therefore, we take the date of immigration from the register data to construct years since migration. Unfortunately, our data do not include information on education, qualifications and occupation acquired in the origin country.

The purpose of this paper threefold: to determine the speed of occupational adjustment across country of origin groups associated with asylum, family and labour migration, to show how the occupational adjustment related to the valuation of education (or skill transferability) and to compare results from alternative measures of occupational attainment. We studied occupational mobility of immigrant groups relative to natives using three different measures of occupational attainment: the International Socio-Economic Index of Occupational Status (ISEI); the five levels of occupations (OL) based on the 1992 standard classification of occupations; and the social-class schema of Erikson, Goldthorpe and Portocarero (EGP) (Evans, 1992; Ganzeboom and Treiman, 1996). Accordingly, we apply estimation techniques fitting the structure of these measures of occupational attainment. Any variation in the estimated occupational adjustment relying on these alternative measures is informative about the validity of the indexes used in earlier studies.

This paper aims to contribute to the relatively small body of literature on occupational mobility of immigrants and to demonstrate both the speed and pattern of adjustment across countries of origin and to document how these correlate with education. In contrast to previous economic literature on occupational mobility of immigrants mainly focused on occupation specific-earnings mobility, the paper studies inter- and intra-occupational mobility of immigrants. In addition, we uniquely use three different measures of occupational outcome to quantify the rate of adjustment: ISEI, OL and EGP. These measures have been designed to capture relative differences in power at workplace (authority), occupational prestige, occupational requirements (education) and occupational rewards (earnings).

Using the labour-force surveys, we estimated the rate of adjustment for the main groups of immigrants in the Netherlands. The analysis shows that the pattern of occupational adjustment of immigrants varies with the country of origin associated with their cultural and linguistic distance from the Dutch society. Mediterranean immigrants start with less-well-qualified but move on to more-highly-qualified jobs as the duration of residence in the Netherlands rises. On the other hand, Caribbean and Western immigrants start with relatively highly-qualified jobs, but their rate of adjustment is relatively low. These adjustment patterns confirm the predictions of the theory of occupational mobility referring to the relationship between the human capital endowment of immigrants at migration and their rate of adjustment in the hostcountry labour-market: immigrants who start at a lower level will have a higher rate of adjustment compared with those who start at a relatively high position. The estimated rates of adjustment are similar across the alternative measures of occupational attainment.

The structure of this paper is as follows. In the next section we present an overview of immigration to the Netherlands. In section three we introduce data and present the descriptive statistics. Section four discusses theoretical background and derives testable hypotheses. In section five, we present the empirical framework and report the regression analysis of immigrants' adjustment patterns in occupations. Section five concludes with a discussion about the implications of the findings.

\section{Immigration to the Netherlands}

Many immigrants to the Netherlands come from Turkey and Morocco; they initially arrived as guest workers in the 1960s and 1970s. Another large group is from Suriname (a former 
Dutch colony), the Dutch Antilles, and Aruba. Recent immigration flows to the Netherlands have mainly comprised family members and asylum immigrants. Most of the family-related migration has been from the 'guest worker' countries from which the largest groups of immigrants originated, such as Turkey and Morocco and the former Dutch colonies of Suriname and the Dutch Antilles. Immigration from Turkey, Morocco, and Suriname is subject to restrictive immigration policies, which have been increasingly tightened since the 1990s. Immigrants from the former colonies are familiar with Dutch society and often speak the language, while Turks and Moroccans have a different religious and cultural background and need to learn the Dutch language after immigration.

During the second half of the 1990s in particular, immigration flows were dominated by asylum seekers from the former Yugoslavia, the former Soviet Union, Iran, Iraq, Afghanistan, China, and so forth. Further tightening of immigration policies at the beginning of the new millennium has substantially hindered asylum migration as well as family migration from Turkey and Morocco. At the same time, the accession of Poland and some other East European countries to the EU has generated legal grounds for immigration from these countries, although it is still subject to some restrictions.

In addition to the immigration from non-western countries, the Netherlands attracts a large number of immigrants from EU countries and other developed countries, such as the USA, Canada, Australia, and Japan. These immigrants are categorized as western immigrants. They enter the Netherlands as labour migrants and perform in the labour market slightly better than the native Dutch do. Flows of these immigrants are highly sensitive to business cycles and are not subject to restrictive immigration policies, unlike the non-western migrants. These labour migrants from western countries are usually highly-educated employees; they are internationally the most mobile group (Bijwaard 2010). They do not face serious institutional restrictions on onward migration when they leave the Netherlands.

The adjustment process of immigrants in the Dutch labour market is strongly affected by the immigration procedure through which they have to pass. Considering the employment performance of non-western immigrants, with particular attention to the four largest immigrant groups, Bevelander and Veenman (2004) and Bevelander and Groeneveld (2006) reported a structural low level of employment and high level of unemployment for two of these groups and their descendants. The first group refers to those who entered the Netherlands as guest workers: Turks and Moroccans. The second group includes immigrants from the former Dutch colonies of Suriname and the Dutch Antilles, who have a relatively better labour-market position compared with the first group. These studies used the SPVA survey, which is a sample from only these four largest immigrant groups in a number of selected cities. Hartog and Zorlu (2009) showed the impact of the particular entry procedure for asylum migrants on their labour market position using administrative data. Indeed, the labour-market outcome is closely related to the way in which immigrants are allowed to enter the Netherlands and to their qualifications. Western immigrants have often arranged a job before they arrive and do not face legal barriers, while non-western immigrants may only enter as family members or asylum immigrants; their entry procedure implies a time period during which they must acquire the legal right to live and work in the country. Moreover, formal qualifications acquired in the origin country are not usually recognized immediately and the immigrants usually need to undergo additional training. These factors may generate a substantial initial disadvantage for non-western immigrants.

\section{Theory and Hypotheses}

Skills of immigrants may not be perfectly transferable across countries due to many differences in the organisation of education systems and labour markets, quality of public 
services, legal and social system between origin and destination countries. The practise of occupations often requires specific qualifications, certifications, occupational licences or credentials. It is also likely that in highly organised societies, these differences can, in turn, serve as invisible tools of restrictive immigration policies, or professional organisations can use these differences to protect interests of their own group.

In labour markets of receiving countries, the transition to the labour market on arrival is not a smooth process. Immigrants' occupational choice is likely to follow a particular trajectory that determines in which part of the earnings distribution immigrants find themselves. On arrival in the host country, the initial choice set of occupations is restricted for immigrants by their deficiency of host-country-specific capital. Country-specific capital refers to a set of relevant formal and informal skills such as qualifications, certifications, licences, language proficiency, social networks and cultural capital, among others. Poor proficiency in the local language and a lack of knowledge about institutions can force immigrants to accept lessfavourable jobs that are often risky and poorly paid. In the beginning of their careers, immigrants experience a very turbulent period in the host country's labour market in which occupational switches dominate earnings growth according to the accumulation of hostcountry-specific capital. Recent evidence suggests that a lower degree of skill transferability generates conditions in which immigrants tend to work in lower-paying occupations (Chiswick and Miller 2008b). Language proficiency plays an important role in generating access to more highly skilled jobs and correspondingly earnings (Chiswick and Miller, 1998; Aldashev et al. 2009; Orrenius and Zavodny, 2009). In addition to language, individuals' demographic characteristics such as race and ethnicity operate through occupations to affect wages (Groshen, 1991).

The degree of skill transferability varies across both levels and sorts of occupations. Highly skilled immigrants will face a potentially lower degree of skill transferability while immigrants with low skills may experience little downward mobility. Some high-level occupations that are tied to a certain country may be less transferable such as lawyers while some other occupations with a high degree of more universalistic characteristics and less strong local-attachment are highly transferable such as computer scientists (Chiswick, Lee and Miller 2005). In addition, the types of skills within an occupation may vary with the level of technology and economic development in the country. Consequently, immigrants from developing countries will experience a low level of skill transferability in a highly developed economy.

The lower the transferability of skills, the greater will be the decline in occupational status from the last job in the origin to the first job in the destination country. In the host country, immigrants will make explicit and implicit investments in host-country specific capital that complement their skills acquired in the origin to increase the transferability of skills to the destination, as well as investments in new skills (Chiswick 1978; Chiswick and Miller 2008a; Duleep and Regets, 1999). The key mechanism behind this process is the functioning of opportunity costs in determining investment into host-country-specific skills. An immigrant with a low-skilled job will have lower opportunity costs for the investment compared with an immigrant with a highly-skilled job, because the wage return is inherently relatively high for the more highly skilled job.

Beyond (given) this type of rational differences, cultural and linguistic distance between origin and destination countries will determine the degree of skill transferability because many differences are very implicit and integrated in social and cultural codes. Initially, immigrants may lack relevant social networks, language skills and cultural capital. The acquisition of cultural capital depends heavily on early and imperceptible learning, performed 
within the family from the earliest days of life (Bourdieu, 1986). Rosholm, Scott and Husted (2006) argue that employment opportunities for immigrants have declined in modern economies as the share of high-skilled jobs has increased and organisation structure has changed. High skilled jobs are associated with the increasing importance of country specific skills that are very much implicit. New jobs are increasingly non-monotonic and require a high degree of interpersonal interactions, language skills, cultural capital and social relations. All these requirements in mind, employers likely statistically discriminate immigrant groups that are perceived not to 'fit' to the profile of a 'standard' employee. The country of origin will be used to categorize immigrants in classes of 'expected productivity' rather than ones human capital accumulation.

Skills of immigrants vary with migration motives. Economic migrants, who are often from other developed countries, plan and prepare their move, and base their migration decision on the quality of job offers. They will experience the least skill transferability problems and a little subsequent improvement. On the other hand, migration decision of refugees is largely determined by non-economic factors such as safety and freedom because of their political ideology, ethnicity, religion etc. As a result, refugee populations are composed of a large share of people whose skills have little international transferability, e.g. generals and lawyers (Chiswick, Lee and Miller 2005). Refugees come from developing countries that are generally in a great cultural and linguistic distance from the destination country. It is therefore likely that refugees will face the steepest decline in occupational status after immigration and a steeper improvement subsequently as they make investments in country-specific capital to increase the transferability of their skills. After all, for refugees, the opportunity costs of these investments will be relatively low, and their return greater since the initial decline in occupational status is the greatest. Similarly, migration decisions of family migrants are strongly influenced by family members or partners of these immigrants who can be either an economic migrant or refugee partner or a native partner. Economic incentives play a possibly less important role. Therefore, also family migrants will face a steeper decline and a steeper subsequent improvement in occupational status, compared to economic migrants, but less steeper compared to refugees.

Our data provide no direct information on migration motive. However, our classification of immigrants into country of origin groups takes into account migration motive and cultural and linguistic distance from the Netherlands. Considering the size of the immigrant groups and the internal similarities in the data, we defined five immigrant groups in addition to the native Dutch. The first group (Mediterrenean) comprises Turks and Moroccans, who have the most similar migration history and socio-economic position. This group includes early 'guest workers' that arrived in the 1960s and 1970s and particularly family migrants who arrived in the 1980s and 1990s. Moreover, these immigrants are predominantly from Muslim origin, whose linguistic and cultural distance from the Dutch is great. Hence, we hypothesize that Mediterranean immigrants would experience the greatest initial disadvantage and correspondingly the steepest improvement in their occupational status (H1).

The second group (Caribbean) comprises Surinamese and Antilleans, who have a colonial history and relationship with the Netherlands and many of whom speak Dutch, unlike other immigrants. This group is quite close to the Dutch society concerning religious and cultural characteristics. It is therefore hypothesized that Caribbean immigrants would experience the low initial disadvantage and subsequently a little improvement in their occupational status (H2).

The third group (Eastern European) comprises East European immigrants who are recent economic migrants. These immigrants comprise higher skills than the Mediterranean, and 
perhaps higher than the Caribbean immigrants. Their cultural and religious background is quite similar to the Dutch people. Yet, East European immigrants are expected to face significant skill transferability problems because they have immigrated in order to search for a job without extensive preparation. Many eastern European immigrants may have qualifications with a low degree of international skill transferability such as those of school teachers or lawyers, because of scarce employment opportunities in origin countries. They usually accept jobs which do not necessarily fit their qualifications. Hence, we hypothesize that Eastern European immigrants would experience the lower initial disadvantage than Mediterranean but a greater disadvantage than Caribbean, and correspondingly a steep improvement in their occupational status (H3).

The fourth group (Refugee) contains Iranian, Iraqi, and Afghani immigrants who are often refugees. This group faces the most disadvantaged initial position because they are at a greatest distance from the Dutch. Their migration decisions have been most likely motivated by non-economic factors and they may have the least cultural, linguistic and social capital. Therefore, we hypothesize that refugees would experience a great initial disadvantage and a steep improvement in their occupational status $(\mathrm{H} 4)$.

The last group (Western) comprises an aggregate of western immigrants for whom labourmarket outcomes are similar to those of the native population. This group includes skilled economic migrants and family migrants who are very similar to the Dutch in terms of their cultural and religious background. Western immigrants have often immigrated to take a prearranged job offer via international companies. We hypothesize that Western immigrants would experience the lowest initial disadvantage and a little subsequent improvement in their occupational status (H5).

\section{Data and Descriptive Statistics}

In contrast with earlier Dutch studies, we used the Labour Force Survey (LFS) from Statistics Netherlands, because these surveys include internationally-comparable measurements of employment, occupations, and education. Moreover, the occupational attainment of the employed labour force is documented in detail, which allows us to capture immigrants' occupational adjustment appropriately. To obtain more observations for immigrant groups, we pooled the data from LFS 2004 and LFS 2005 and restricted the sample to employed people aged 15 to 65 years. The LFS contains information about education in addition to a large number of variables. However, no distinction is drawn between education acquired in the home country and that acquired in the Netherlands. The age at immigration can reveal the level of foreign education, but not additional education acquired in the Netherlands. Our experiment with age at immigration and corresponding education level suggests that the education level of immigrants might be much the same as education acquired abroad. There is unfortunately also no information about proficiency in the Dutch language in the LFS. The duration of residence can capture the effects of possible post-immigration investment in education and language.

A common characteristic of Mediterranean and Caribbean immigrants is the continual immigration flows from the origin countries induced by family reunification and formation, and very little return migration. It is reasonable to assume that the relevant skills of successive immigration cohorts from these countries have not changed over time. The international mobility of Antilleans is relatively high because of the free mobility between the Dutch Antilles and the Netherlands. However, Antillean immigrants comprise less than one third of the Caribbean sub-sample, and excluding them from the sample has no impact on the estimates. 
As mentioned above, the international mobility of western immigrants is particularly high and the return migration may be selective. If return migrants were the more able and the survivors the less able, our estimates for this group would be an underestimate of the effect of duration of stay. The duration of residence in the Netherlands is taken from the municipal rolls ${ }^{1}$ (Gemeentelijke Basis Administratie) and is specified in five interval categories: YSM up to 3 years, YSM 3-5 years, YSM 6-9 years, YSM 10-15 years and YSM >15 years. The breakpoints of these categories are identified through the help of experiments. This methodology allows us to identify clear adjustment patterns across immigrant groups relative to the native Dutch.

Since occupational status is strongly correlated with educational level, the estimates of occupational attainment for education have to be controlled for. The LFS includes information on education in categories rather than years of education. The best measure of educational skills in the Netherlands consists of a classification in seven categories of completed education in general and vocational trajectories: primary education (BO), lower secondary vocational (VBO), lower secondary general (MAVO), secondary general (HAVO and VWO), secondary vocational (MBO), higher vocational (HBO) and university (WO)

The variables in table 1 explain the differences in the occupational positions of immigrants and the Dutch. Table 1 presents the mean values of the covariates by gender and immigrant group. It is immediately apparent that the Mediterranean immigrants have the most unfavourable characteristics. They have the lowest educational levels and a low level of female participation. Refugees and East European immigrants have the lowest duration of residence in the Netherlands. These new immigrants are quite similar in most of their characteristics, with one obvious exception: the majority of East European immigrants are women while only 28 percent of employed refugees are women. Refugees, Mediterranean, and East European immigrants are relatively young compared with the native population. They also have children younger than 12 more often than the native Dutch do. Mediterranean immigrants have a particularly high frequency of children younger than 12 years. The characteristics of western immigrants are more similar to those of the native population. Strikingly, the share of East European and Western immigrants as well as Refugees who have a university education is higher than for the native Dutch. Among non-western immigrants, Caribbean immigrants have a particular position in that they share a common history with the Netherlands as a result of colonial relations. Almost 90 percent of Caribbean immigrants have Dutch nationality.

Table 1. Means of variables by ethnic group, age 15 - 64

\begin{tabular}{lcccccc}
\hline & Dutch & \multicolumn{5}{c}{ Mediterran. Caribbean EastEurop Refugees Western } \\
\hline YSM < 3 years & & 0.03 & 0.02 & 0.04 & 0.01 & 0.05 \\
YSM 3-5 years & & 0.07 & 0.06 & 0.11 & 0.14 & 0.10 \\
YSM 6-9 years & & 0.11 & 0.10 & 0.21 & 0.40 & 0.14 \\
YSM 10-15 years & & 0.25 & 0.20 & 0.43 & 0.35 & 0.19 \\
YSM >15 years & & 0.53 & 0.61 & 0.21 & 0.09 & 0.51 \\
Edu- Primary & 0.05 & 0.25 & 0.10 & 0.07 & 0.07 & 0.04 \\
Edu-MAVO & 0.09 & 0.04 & 0.08 & 0.05 & 0.04 & 0.04 \\
\hline
\end{tabular}

\footnotetext{
${ }^{1}$ Note that the registration is conditional on having a residence permit although this rule was not strictly applied before 2001. Refugees usually face a significant delay in registration because they should first go through a longlasting asylum procedure to earn a residence permit.
} 


\begin{tabular}{lrrrrrr}
\hline Edu-VBO & 0.13 & 0.16 & 0.12 & 0.07 & 0.12 & 0.05 \\
Edy-HAVO & 0.09 & 0.18 & 0.11 & 0.20 & 0.19 & 0.16 \\
Edu-MBO & 0.34 & 0.22 & 0.36 & 0.35 & 0.26 & 0.35 \\
Edu-HBO & 0.20 & 0.04 & 0.16 & 0.04 & 0.05 & 0.08 \\
Edu-WO & 0.10 & 0.06 & 0.05 & 0.20 & 0.26 & 0.25 \\
Woman & 0.45 & 0.30 & 0.53 & 0.55 & 0.28 & 0.51 \\
Age & 39.14 & 36.45 & 41.58 & 37.61 & 35.43 & 43.34 \\
Married & 0.56 & 0.54 & 0.46 & 0.54 & 0.56 & 0.51 \\
One child 0-5 years & 0.12 & 0.32 & 0.14 & 0.18 & 0.21 & 0.13 \\
2-5 children 0-5 years & 0.07 & 0.13 & 0.05 & 0.06 & 0.09 & 0.06 \\
Children 6-11 years & 0.19 & 0.42 & 0.22 & 0.24 & 0.25 & 0.18 \\
Naturalized & & 0.19 & 0.86 & 0.19 & 0.09 & 0.33 \\
& & & & & & \\
\hline $\mathrm{N}$ & 111597 & 1467 & 1450 & 736 & 327 & 2215 \\
\hline
\end{tabular}

\section{Empirical Approach}

In this paper we consider immigrants' adjustment patterns in occupational attainment through applying the theory of occupational mobility of immigrants. Appropriate data for this purpose was derived from the Dutch Labour Force Survey (LFS), although it has no information about the language ability of immigrants. The main advantage of the LFS is that this survey measures the labour-market position and occupational attainment of individuals in detail according to the international definitions that make international comparisons possible. To obtain more statistical power for relatively-small immigrant groups, we have used two waves of the survey: LFS 2004 and LFS 2005.

Using cross-sectional data can potentially provide biased estimates for the duration of residence because the analysis cannot deal properly with possible changes in the quality of immigration cohorts, selective return migration, or changes in economic conditions that have lasting effects ${ }^{2}$ (Borjas 1995; Chiswick, Cohen and Zach, 1997). This issue has been extensively debated in the US. In our case, changing cohort quality and selective return migration are probably less serious problems as long as we distinguish immigrants by origin country. Return migration to non-western origin countries is quite low and does not often take place on the basis of a voluntarily choice; there is some indication that the quality of successive immigration cohorts from individual countries seems to be stable within the main source countries (Zorlu and Hartog 2009). We have therefore used cross-section data because LFS has many advantages. Ideally, adjustment of immigrants can be studied using longitudinal data. However, for the Netherlands, no suitable longitudinal data are available. Longitudinal register data for the Netherlands (SSD) include unfortunately no information on education and occupations.

For the analysis, the rate of adjustment in the Dutch labour market is a key variable measured by the five intervals of year since migration (YSM). To estimate the adjustment of immigrants we used the following general regression model

\footnotetext{
2 To limit potential biases in the estimates, we experimented to include the unemployment rate at the year of immigration in regression models since particularly labour migration is highly sensitive to the business cycles (Bijwaard, 2010). Including the unemployment rate did not lead to different estimates for occupational adjustment across the origin countries. It is likely that unobserved quality differences between immigrants from different source countries are far more important than differences over time for a given source country. Some of the relevant unobserved qualities obviously correlate with education and this will restrain the bias in the estimated effect of YSM. However, this will bias the coefficient of education.
} 


$$
Y_{i}=\beta A_{i j, Y S M}+\gamma X_{i}+\varepsilon_{i}
$$

where $Y$ is the occupational outcome of immigrant $i, A_{i j, Y S M}$ measures the rate of the adjustment of immigrant $i$ from immigrant group $j$ with a duration of residence interval YSM relative to the Dutch ${ }^{3}, X_{i}$ is a vector of other individual characteristics that potentially determine employment and occupational outcome, such as age, education, marital status, the presence of children, and $\varepsilon_{i}$ is an error term. This model does not include the age at migration because this variable is correlated with YSM and actual age. In order to see effects of this omission, we also estimated models with the age at migration. As expected, the estimates for YSM categories declined because a part of the adjustment effects were picked up by the age at migration. However, including the age at migration in the model had a very limited effect on adjustment patterns the across origin countries. Nevertheless, we have chosen to report the estimates from models without the age at migration to provide a clearer picture of occupational adjustment which is represented by a single variable, YSM.

We examined occupational adjustment using three different measures of occupational outcome which were originally designed to emphasize various aspects of occupational attainment. Each of these measures is estimated using an appropriate estimator according to the nature of the dependent variable. First, we used a linear model to estimate the International Socio-Economic Index of Occupational Status (ISEI) (Ganzeboom and Treiman, 1996). In the second case, we applied an ordered logit estimator to estimate the rank-ordered five levels of occupations (elementary, low, medium, high, and scientific) that correspond with the formal requirements for level of education ${ }^{4}$. In the third measure of occupation, we applied a multinomial logit model to the three categories of the EGP social class schema ${ }^{5}$, namely professional, intermediate, and unskilled, treating these three classes as independent categories rather than a natural rank order (Evans, 1992). Although all three types of occupational measure are coded on the ISCO occupational categories and rely heavily on level of education, they allow us to study various aspects of occupational attainment.

The ISEI index (a continuous variable ranging from 15 to 86) captures the attributes of occupations so that occupation can serve as an intervening variable between education and income. A linear-regression model evaluates ethnic differences in mean values of variables. The five levels of occupation (OL) are a simple measure of occupational attainment and are constructed on the basis of the formal educational requirements of occupations in ascending rank order: elementary, low, medium, high, and scientific. An ordered logit model assesses ethnic differences in relation with these five occupation levels. A standard ordered logit model assumes the proportionality of odds and provides one parameter for each explanatory variable across the levels. Furthermore, an estimation of OL covers the complete distribution of occupations and evaluates ethnic differences in terms of the mean values of variables. Finally, the EGP social-class schema is based mainly on the relationships of ownership and authority and is used by social-stratification researchers who argue that members of society

\footnotetext{
${ }^{3}$ We prefer to use five YSM-intervals (YSM<3, YSM3-5, YSM 6-9, YSM10-15 and YSM>15) rather than a continuous YSM variable. This strategy allows us to compare immigrants from a YSM interval with the native Dutch directly taking into account that each YSM interval has a sufficient number of observations, and these intervals reflect the general pattern of adjustment over the whole range of YSM.

${ }^{4}$ These five levels of occupations were constructed by Statistics Netherlands and are readily available in the LFS.

${ }^{5}$ The eight original categories are clustered into three groups referring to professional (I and II), intermediate (IIIa, IV, V and VI) and unskilled (IIIb and VII)
} 
are divided into a limited number of discrete categories (classes). Among the three categories of EGP, 'unskilled' is of particular importance for immigrants from developing countries since their first jobs are often at the lower end of the occupation distribution, given their education level. Immigrants' concentration in this category, the probability of their being in one of the EGP categories, is estimated by a multinomial logit model taking the professional category as the reference for which the coefficients are normalized to zero ${ }^{6}$. The estimation of this model provides parameter estimates for the unskilled, the category of interest, and intermediate, to which no particular attention is paid. Once again, the focus here is on the relative probability of having an unskilled job.

Since occupational attainment is measured only for the employed labour force, our estimates may be biased if there is (self-) selection into employment. For instance; if immigrants from non-western countries, who face significant difficulties in finding employment, are positively (self-) selected into employment, our estimates for adjustment would be upwardly biased. To verify this hypothesis, we estimated the probability of employment with correction for selection (Heckman selection model) as described by Van de Ven and Van Praag (1981). To be able to estimate the Heckman selection model, we need at least one instrument which should be included in the selection equation but not in the employment equation. In our data, there are two variables which may potentially serve as instruments: the number of children and the degree of urbanisation. We estimated Heckman selection models using these variables as instruments. Surprisingly, our estimations indicated a negative selection into employment: those who have a lower probability of employment tend to participate more likely in the labour market. This counter intuitive result can arise from inappropriate instruments.

\subsection{Occupational Attainment}

Table 2 shows the occupational status of immigrants according to the three measures of occupational attainment. The first column shows the mean values of the ISEI index. The distribution of the labour force over the five occupation levels is shown in columns 2 to 6 . The last three columns give the distribution of the working population across the three EGP categories. It is immediately apparent that Mediterranean immigrants are mostly concentrated at the bottom of the occupational distribution among other immigrant groups. Their ISEI score is 10 points lower than for the average Dutch and about 31.5 percent of them are employed in unskilled occupations compared with about 9 percent of the Dutch. When we look at the EGP distribution, about 60 percent of Mediterranean immigrants are in unskilled jobs. Their presence in the higher occupational categories is conspicuously low. Refugees and East European immigrants follow Mediterranean immigrants in rank order. Caribbean immigrants are employed in relatively high-ranked occupations while Western immigrants have a position comparable with the Dutch. They are even slightly more highly represented in the highest-ranked occupations.

\footnotetext{
${ }^{6}$ The three categories of EGP are not necessarily ordered rather than the names of these categories suggest. As described, these categories base on eight underlying original groups measuring different aspects of occupational attainment. Therefore, we prefer to use multinomial logit model rather than ordered logit because the former has the advantage to treat each outcome separately relative to the base category. Moreover, our emphasis is on unskilled labour and we are able to see occupational adjustment within this category.
} 
Table 2. Occupational attainment

\begin{tabular}{|c|c|c|c|c|c|c|c|c|c|}
\hline & ISEI & \multicolumn{5}{|c|}{ OL (in \%) } & \multicolumn{3}{|c|}{ EGP (in \%) } \\
\hline & (mean) & Element & Lower & Middle & Higher & Scientif & Unskill & Interm & Profes \\
\hline Dutch & 46.0 & 8.7 & 25.3 & 37.4 & 21.1 & 7.5 & 29.9 & 34.0 & 36.0 \\
\hline Mediterren. & 34.5 & 31.5 & 35.3 & 24.9 & 6.8 & 1.5 & 60.5 & 25.7 & 13.8 \\
\hline Caribbean & 42.0 & 17.0 & 27.9 & 36.3 & 14.9 & 4.0 & 41.1 & 32.4 & 26.6 \\
\hline East Eur. & 40.2 & 20.9 & 32.2 & 30.2 & 11.7 & 5.0 & 45.6 & 33.1 & 21.3 \\
\hline Refugee & 39.3 & 19.9 & 38.7 & 24.7 & 9.5 & 7.1 & 55.4 & 24.7 & 19.9 \\
\hline Western & 47.3 & 10.5 & 25.9 & 30.6 & 24.2 & 8.9 & 31.9 & 28.0 & 40.2 \\
\hline
\end{tabular}

\subsection{Estimates of ISEI and OL}

Table 3 provides OLS estimations of the ISEI and Ordered Logit estimations of OL. We ran OLS and Ordered Logit models first without education variables and then including seven categories of completed educational levels to assess the contribution of education in the explanation of differences between the immigrant groups and the Dutch. Indeed, higher education is strongly associated with higher occupational attainment. The ISEI index for a university graduate is 33 points higher than for a person with just primary education (the reference category). The pattern of immigrants' disadvantage is similar for both measures of occupational attainment, the ISEI and OL, as figure 1 shows, although the estimation methods were different. On arrival, Mediterranean and to a lesser extent East European immigrants start with the greatest disadvantage, and they substantially improve their position the longer the duration of residence is, which confirms the hypotheses H1 and H3. However, they never catch up with the native Dutch. Caribbean and Western immigrants do not catch up with the Dutch either although they start from a relatively less disadvantaged position. Immigrants' disadvantage in occupational attainment seems to be consistent over time.

The impact of education on the estimated gap for immigrants with the varying duration of residence intervals relative to the native Dutch is also worthy of discussion, since immigrants' disadvantage largely emerges through an undervaluation of their education. Figures $1 \mathrm{a}$ and $1 \mathrm{~b}$ plot the adjustment profiles for immigrant groups on the basis of the parameter estimates for the linear models of the ISEI measures and the ordered logit models of OL with and without education controls, to facilitate comparison. Including education in the regression models has relatively little impact on the Dutch-immigrant occupational gap in the early years of residence among Mediterranean immigrants, but this effect increases with the duration of residence. For Caribbean immigrants, the impact of education is slightly lower for the YSM interval up to 3 years, after which time it remains significant and almost constant. For the other immigrant groups (East European, Refugee, and Western) including education in the models does not reduce, but rather increases, the ethnic gap. This effect is stronger for Western immigrants for whom the ethnic gap is not significant when education is excluded, but becomes significant when it is included in the model. This suggests that Western and East European immigrants are relatively more highly educated than the Dutch but are not employed proportionally in more highly-skilled jobs. Foreign education is thus systematically undervalued for Mediterranean immigrants as well as for Western immigrants, while Caribbean immigrants do not face a significant skill transferability problem at the beginning of their careers in the Dutch labour market as hypothesized (H1, H2 and H5). In other words, the skill transferability is less than optimal even for Western immigrants. For Refugee immigrants, neither the impact of education nor the pattern of adjustment shows a consistent pattern. This result does not support the hypothesis H4, and is possibly caused by the strong 
heterogeneity of successive immigration cohorts from Iran, Iraq, and Afghanistan and a changing dominance of origin country in immigration flows.

Table 3. Estimates of ISEI and Occupation levels

\begin{tabular}{|c|c|c|c|c|}
\hline & OLS & OLS & Ordered L & Ordered L \\
\hline & Basic Model & $\begin{array}{l}\text { Model with } \\
\text { Education }\end{array}$ & Basic Model & $\begin{array}{l}\text { Model with } \\
\text { Education }\end{array}$ \\
\hline Mediter*YSM $<3$ years & $\begin{array}{l}-18.826 * * * \\
(1.248)\end{array}$ & $\begin{array}{l}-17.085^{* * *} \\
(1.805)\end{array}$ & $\begin{array}{l}-2.954^{* * *} \\
(0.285)\end{array}$ & $\begin{array}{l}-3.782^{* * *} \\
(0.583)\end{array}$ \\
\hline Mediter*YSM 3-5 years & $\begin{array}{l}-17.326 * * * \\
(0.934)\end{array}$ & $\begin{array}{l}-15.404^{* * *} \\
(1.232)\end{array}$ & $\begin{array}{l}-2.580^{* * *} \\
(0.193)\end{array}$ & $\begin{array}{l}-3.115^{* * *} \\
(0.373)\end{array}$ \\
\hline Mediter*YSM 6-9 years & $\begin{array}{l}-14.373^{* * *} \\
(0.884)\end{array}$ & $\begin{array}{l}-9.770 * * * \\
(0.960)\end{array}$ & $\begin{array}{l}-2.006^{* * *} \\
(0.140)\end{array}$ & $\begin{array}{l}-1.878 * * * \\
(0.221)\end{array}$ \\
\hline Mediter*YSM 10-15 years & $\begin{array}{l}-13.124^{* * *} \\
(0.708)\end{array}$ & $\begin{array}{l}-7.743^{* * *} \\
(0.708)\end{array}$ & $\begin{array}{l}-1.823^{* * *} \\
(0.112)\end{array}$ & $\begin{array}{l}-1.296^{* * *} \\
(0.136)\end{array}$ \\
\hline Mediter*YSM >15 years & $\begin{array}{l}-13.228^{* * *} \\
(0.506)\end{array}$ & $\begin{array}{l}-6.207 * * * \\
(0.582)\end{array}$ & $\begin{array}{l}-1.749 * * * \\
(0.077)\end{array}$ & $\begin{array}{l}-1.037^{* * *} \\
(0.106)\end{array}$ \\
\hline Carib*YSM $<3$ years & $\begin{array}{l}-7.358 * * \\
(2.654)\end{array}$ & $\begin{array}{l}-5.176 \\
(2.764)\end{array}$ & $\begin{array}{l}-0.986^{* *} \\
(0.359)\end{array}$ & $\begin{array}{l}-0.977^{*} \\
(0.451)\end{array}$ \\
\hline Carib*YSM 3-5 years & $\begin{array}{l}-9.593^{* * * *} \\
(1.650)\end{array}$ & $\begin{array}{l}-6.110^{* * * *} \\
(1.422)\end{array}$ & $\begin{array}{l}-1.448^{* * * *} \\
(0.240)\end{array}$ & $\begin{array}{l}-1.255^{* * *} \\
(0.264)\end{array}$ \\
\hline Carib*YSM 6-9 years & $\begin{array}{l}-7.004^{* * * *} \\
(1.405)\end{array}$ & $\begin{array}{l}-4.606 * * * \\
(1.096)\end{array}$ & $\begin{array}{l}-0.889 * * * \\
(0.188)\end{array}$ & $\begin{array}{l}-0.811^{* * *} \\
(0.193)\end{array}$ \\
\hline Carib*YSM 10-15 years & $\begin{array}{l}-6.102^{* * * *} \\
(0.970)\end{array}$ & $\begin{array}{l}-3.409 * * * \\
(0.822)\end{array}$ & $\begin{array}{l}-0.876^{* * * *} \\
(0.134)\end{array}$ & $\begin{array}{l}-0.811^{* * *} \\
(0.147)\end{array}$ \\
\hline Carib*YSM >15 years & $\begin{array}{l}-7.524 * * * \\
(0.733)\end{array}$ & $\begin{array}{l}-4.250 * * * \\
(0.755)\end{array}$ & $\begin{array}{l}-0.919 * * * \\
(0.096)\end{array}$ & $\begin{array}{l}-0.716^{* * *} \\
(0.130)\end{array}$ \\
\hline East*YSM $<3$ years & $\begin{array}{l}-12.576^{* * *} \\
(1.794)\end{array}$ & $\begin{array}{l}-12.501^{* * *} \\
(2.342)\end{array}$ & $\begin{array}{l}-1.778^{* * * *} \\
(0.355)\end{array}$ & $\begin{array}{l}-2.464^{* * *} \\
(0.616)\end{array}$ \\
\hline East*YSM 3-5 years & $\begin{array}{l}-5.778 * * \\
(1.784)\end{array}$ & $\begin{array}{l}-9.447 * * * \\
(1.421)\end{array}$ & $\begin{array}{l}-0.826^{* * * *} \\
(0.240)\end{array}$ & $\begin{array}{l}-1.801^{* * *} \\
(0.314)\end{array}$ \\
\hline East*YSM 6-9 years & $\begin{array}{l}-5.463^{* * * *} \\
(1.238)\end{array}$ & $\begin{array}{l}-6.759 * * * \\
(1.056)\end{array}$ & $\begin{array}{l}-0.900^{* * *} \\
(0.177)\end{array}$ & $\begin{array}{l}-1.525^{* * *} \\
(0.227)\end{array}$ \\
\hline East*YSM 10-15 years & $\begin{array}{l}-6.418^{* * * *} \\
(0.889)\end{array}$ & $\begin{array}{l}-6.742 * * * \\
(0.783)\end{array}$ & $\begin{array}{l}-0.962 * * * \\
(0.118)\end{array}$ & $\begin{array}{l}-1.436^{* * *} \\
(0.153)\end{array}$ \\
\hline East*YSM $>15$ years & $\begin{array}{l}-7.534 * * * \\
(1.266)\end{array}$ & $\begin{array}{l}-7.322 * * * \\
(1.158)\end{array}$ & $\begin{array}{l}-0.841 * * * \\
(0.168)\end{array}$ & $\begin{array}{l}-1.104^{* * * *} \\
(0.209)\end{array}$ \\
\hline Refugee*YSM $<3$ years & $\begin{array}{l}-10.569 \\
(8.713)\end{array}$ & $\begin{array}{l}-4.440 \\
(5.342)\end{array}$ & $\begin{array}{l}-2.726^{*} \\
(1.354)\end{array}$ & $\begin{array}{l}-2.414^{* *} \\
(0.891)\end{array}$ \\
\hline Refugee*YSM 3-5 years & $\begin{array}{l}-4.058 \\
(2.629)\end{array}$ & $\begin{array}{l}-5.287^{*} \\
(2.569)\end{array}$ & $\begin{array}{l}-0.939 * * \\
(0.341)\end{array}$ & $\begin{array}{l}-1.329 * \\
(0.536)\end{array}$ \\
\hline Refugee*YSM 6-9 years & $\begin{array}{l}-8.996^{* * * *} \\
(1.370)\end{array}$ & $\begin{array}{l}-9.832 * * * \\
(1.331)\end{array}$ & $\begin{array}{l}-1.300^{* * *} \\
(0.178)\end{array}$ & $\begin{array}{l}-1.910^{* * *} \\
(0.274)\end{array}$ \\
\hline Refugee*YSM 10-15 years & $\begin{array}{l}-7.045^{* * *} \\
(1.408)\end{array}$ & $\begin{array}{l}-9.554^{* * *} \\
(1.455)\end{array}$ & $\begin{array}{l}-0.817^{* * *} \\
(0.174)\end{array}$ & $\begin{array}{l}-1.541^{* * *} \\
(0.268)\end{array}$ \\
\hline Refugee*YSM >15 years & $\begin{array}{l}1.400 \\
(3.226)\end{array}$ & $\begin{array}{l}-3.761 \\
(2.157)\end{array}$ & $\begin{array}{l}0.466 \\
(0.421)\end{array}$ & $\begin{array}{l}-0.307 \\
(0.296)\end{array}$ \\
\hline West*YSM $<3$ years & $\begin{array}{l}1.920 \\
(1.628)\end{array}$ & $\begin{array}{l}-5.138^{* * * *} \\
(1.415)\end{array}$ & $\begin{array}{l}-0.018 \\
(0.220)\end{array}$ & $\begin{array}{l}-1.528^{* * * *} \\
(0.269)\end{array}$ \\
\hline
\end{tabular}




\begin{tabular}{|c|c|c|c|c|}
\hline West*YSM 3-5 years & $\begin{array}{l}0.736 \\
(1.066)\end{array}$ & $\begin{array}{l}-3.756^{* * * *} \\
(0.982)\end{array}$ & $\begin{array}{l}-0.159 \\
(0.137)\end{array}$ & $\begin{array}{l}-1.167^{* * *} \\
(0.177)\end{array}$ \\
\hline West*YSM 6-9 years & $\begin{array}{l}1.277 \\
(0.925)\end{array}$ & $\begin{array}{l}-3.005^{* * *} \\
(0.775)\end{array}$ & $\begin{array}{l}0.031 \\
(0.125)\end{array}$ & $\begin{array}{l}-0.948^{* * * *} \\
(0.157)\end{array}$ \\
\hline West*YSM 10-15 years & $\begin{array}{l}0.384 \\
(0.746)\end{array}$ & $\begin{array}{l}-2.608 * * * \\
(0.743)\end{array}$ & $\begin{array}{l}-0.074 \\
(0.094)\end{array}$ & $\begin{array}{l}-0.773^{* * *} \\
(0.137)\end{array}$ \\
\hline West*YSM <15 years & $\begin{array}{l}-2.165^{* * *} \\
(0.574)\end{array}$ & $\begin{array}{l}-2.949 * * * \\
(0.778)\end{array}$ & $\begin{array}{l}-0.353^{* * *} \\
(0.075)\end{array}$ & $\begin{array}{l}-0.657^{* * * *} \\
(0.136)\end{array}$ \\
\hline Edu-mavo & & $\begin{array}{l}7.189 * * * \\
(0.175)\end{array}$ & & $\begin{array}{l}0.805 * * * \\
(0.029)\end{array}$ \\
\hline Edu-vbo & & $\begin{array}{l}2.321^{* * *} \\
(0.158)\end{array}$ & & $\begin{array}{l}0.588 * * * \\
(0.027)\end{array}$ \\
\hline Edu-havo & & $\begin{array}{l}13.703^{* * * *} \\
(0.177)\end{array}$ & & $\begin{array}{l}2.240 * * * \\
(0.031)\end{array}$ \\
\hline Edu-mbo & & $\begin{array}{l}9.541^{* * *} \\
(0.148)\end{array}$ & & $\begin{array}{l}2.257 * * * \\
(0.026)\end{array}$ \\
\hline Edu-hbo & & $\begin{array}{l}23.736^{* * *} \\
(0.157)\end{array}$ & & $\begin{array}{l}4.782 * * * \\
(0.031)\end{array}$ \\
\hline Edu-wo & & $\begin{array}{l}33.097 * * * \\
(0.176)\end{array}$ & & $\begin{array}{l}6.947 * * * \\
(0.042)\end{array}$ \\
\hline Woman & $\begin{array}{l}-0.038 \\
(.0850)\end{array}$ & $\begin{array}{l}-0.0129 \\
(0.067)\end{array}$ & $\begin{array}{l}-0.155^{* * *} \\
(0.010)\end{array}$ & $\begin{array}{l}-0.246^{* * *} \\
(0.011)\end{array}$ \\
\hline cut1 & & & $\begin{array}{l}2.683 * * * \\
(0.049)\end{array}$ & $\begin{array}{l}2.438 * * * \\
(0.058)\end{array}$ \\
\hline cut2 & & & $\begin{array}{l}4.504 * * * \\
(0.051)\end{array}$ & $\begin{array}{l}4.697 * * * \\
(0.060)\end{array}$ \\
\hline cut3 & & & $\begin{array}{l}6.183 * * * \\
(0.052)\end{array}$ & $\begin{array}{l}7.427 * * * \\
(0.061)\end{array}$ \\
\hline cut4 & & & $\begin{array}{l}7.801 * * * \\
(0.053)\end{array}$ & $\begin{array}{l}10.249 * * * \\
(0.065)\end{array}$ \\
\hline r2_a & 0.071 & 0.439 & & \\
\hline $\mathrm{N}$ & 128036 & 128036 & 128036 & 128036 \\
\hline
\end{tabular}

The models estimated also include controls for quadratic age and marital status, naturalization, and 3 control variables for the number of children between 0 and 5 , and between 6 and 11 years.

Figure 1a. Adjustment profile in ISEI by immigrant group; the coefficients obtained from OLS models with and without education variables 

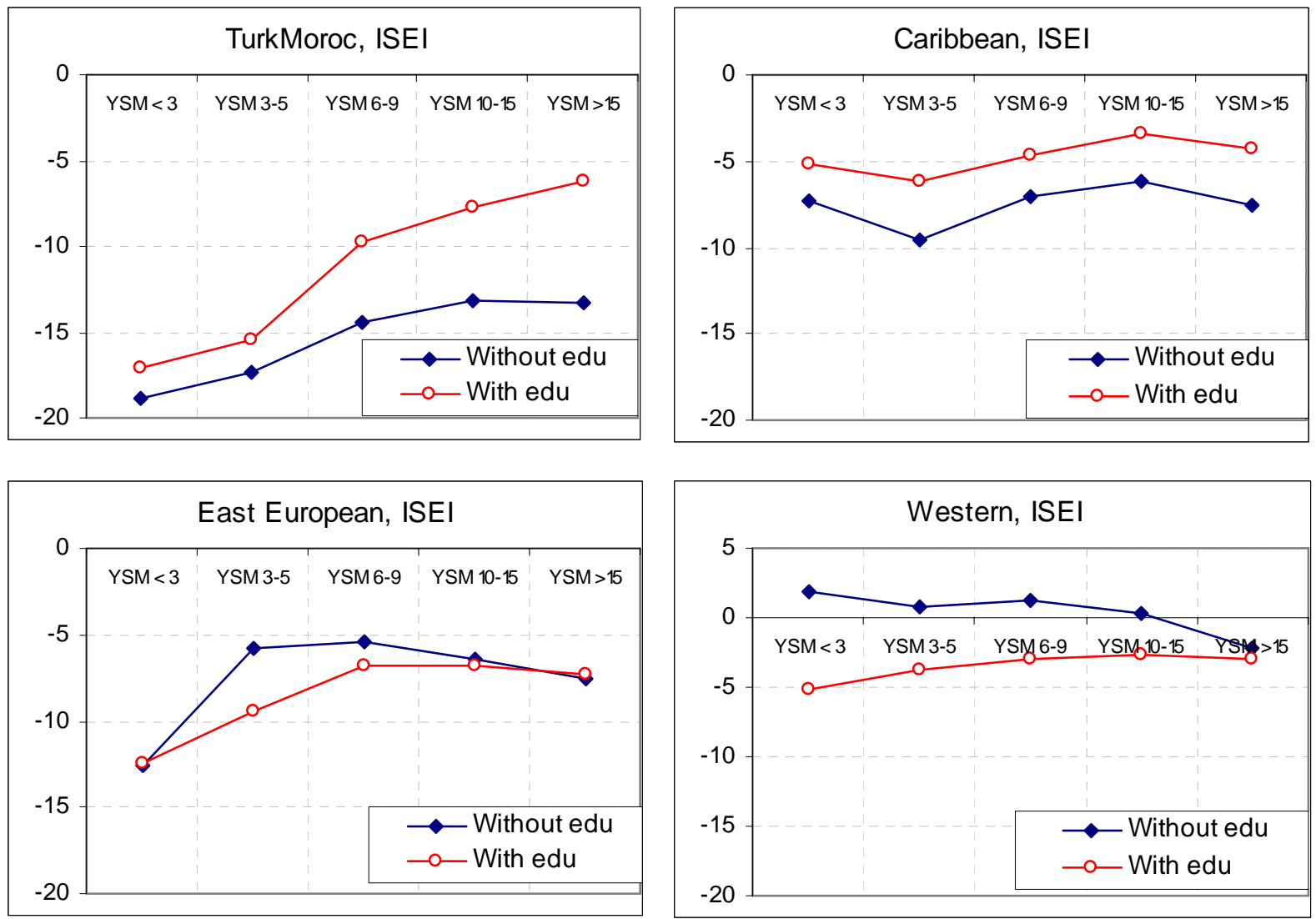

Figure 1b. Adjustment profile in OL by immigrant group; the coefficients obtained from ordered logit models with and without education variables
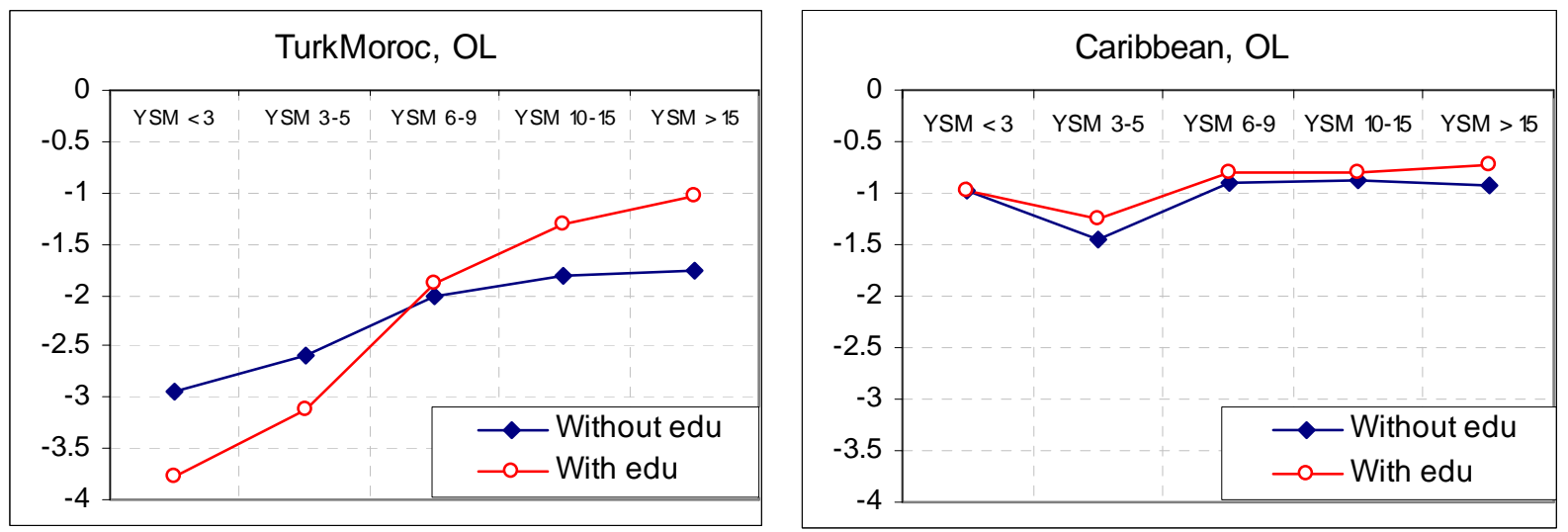

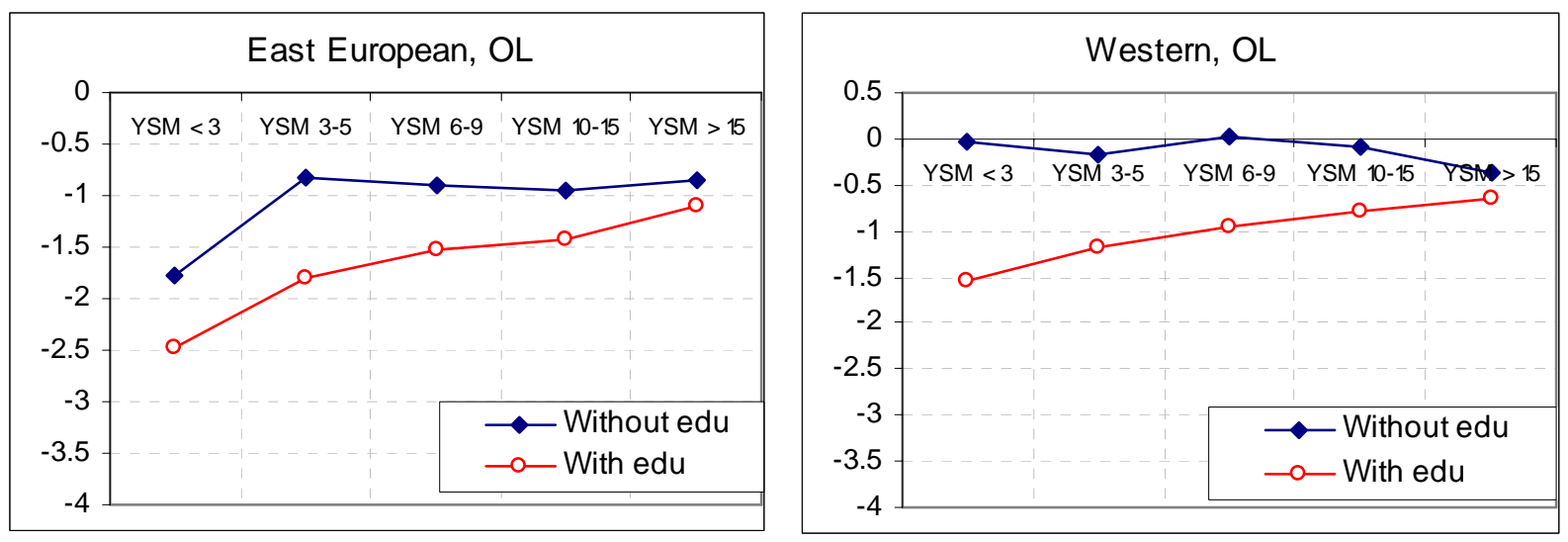

\subsection{Estimates of EGP}

The estimations of ISEI and OL cover the complete occupational distribution and express native-immigrant differences in means. The particular concentration of non-western immigrants at the bottom of the occupational distribution may be masked by these estimation methods. To account for immigrants' high concentration at the bottom of the occupational distribution, we focus on the probability of having an unskilled job. Table 4 presents the parameter estimates of multinomial logit models for the outcomes Intermediate and Unskilled relative to the outcome Professional. The primary concern is to assess the adjustment profiles of immigrant groups in Unskilled occupations in which mobility is most apparent. So, no particular attention has been paid to the parameters for Intermediate occupations. To facilitate interpretation, we also present the marginal effects for the immigrant groups that indicate the relative overrepresentation of immigrants in unskilled occupations compared with the Dutch. These marginal effects are in fact elasticities and they also rely on the values of the other covariates that are included in the models but not presented in table 4, such as age, gender, marital status, children and naturalisation.

Strikingly, the impact of education on the probability of having an unskilled job is similar to that of the other measures of occupational attainment (ISEI and OL) for Western and East European immigrants. When the controls for education level are included in the model, the disadvantage becomes significant for these immigrants. Including education controls in the model increases the disadvantage for Mediterranean immigrants who have been in the Netherlands for less than 10 years and reduces the disadvantage for those who have been there longer than 10 years. This outcome suggests a higher valuation of education and a higher rate of adjustment as their duration of residence increases. For Caribbean immigrants, including education controls reduces the disadvantages for any duration of residence interval, which underlines again the relatively ease of skill transferability for this group. In other words, the valuation of their education is almost constant over time.

The most notable finding is that almost all the Mediterranean immigrants who are employed in the first few years of residence have unskilled jobs. The initial probability of having an unskilled job is 68 percentage points higher than for the Dutch. These immigrants improve their occupational position, the longer they stay in the Netherlands, as stated by the hypothesis H1. The gap reduces to 18 percentage points for Mediterranean immigrants who have been in the Netherlands for longer than 15 years. The concentration of Caribbean immigrants in unskilled jobs is about 32 percentage points higher than for the Dutch for the first two years of stay, but this difference is not statistically significant, and decreases to 17 percentage points when the duration of residence exceeds six years. East European immigrants start with a gap 
of 39 percentage points, which declines to 16 percentage points when they have been in the Netherlands for more than 15 years. The overrepresentation of western immigrants in unskilled jobs is 31 percentage points on arrival and declines to 11 percentage points after 10 years, which is the lowest level among all immigrant groups. The lower initial disadvantage and subsequent improvement for Caribbean, East European and Western immigrants confirm the hypotheses H2, H3 and H5, similar to the other measures of occupational attainment. The adjustment pattern for refugees is again unclear; it does not follow a consistent line, which provides no evidence for the hypothesis $\mathrm{H} 4$.

Comparing the relative likelihood of having an unskilled job over the duration of residence among the immigrant groups, we can conclude that the predictions of the Dip \& Catch-Up model apply to the adjustment pattern of immigrant groups. Figure 2 indicates that Mediterranean immigrants start with the largest gap but that the rate of adjustment is significantly higher for them than for Caribbean and Western immigrants who start with a much smaller gap and end up with a slightly smaller gap. So, the slope of decline is substantially smaller than for the Mediterranean immigrants. The initial disadvantage of East European immigrants is also substantial, just below that for Mediterranean immigrants. These two groups end up at a similar level of disadvantage, which suggests a slightly slower rate of adjustment for East European immigrants.

Table 4. Multinomial logit estimates of the likelihood of the immigrant groups of being in Unskilled and Intermediate jobs relative to the Dutch; coefficients, (standard errors), [marginal effects]

\begin{tabular}{lllll}
\hline & \multicolumn{2}{l}{ Basic Model EGP } & \multicolumn{2}{l}{ Model with education EGP } \\
\hline & Intermed. & Unskilled & Intermed. & Unskilled \\
\hline Mediter*YSM < 3 years & 0.665 & $3.933^{* * *}$ & 1.709 & $5.064^{* * *}$ \\
& $(1.225)$ & $(1.027)$ & $(1.391)$ & $(1.251)$ \\
Mediter*YSM 3-5 years & {$[-.31]$} & {$[.64]$} & {$[-.36]$} & {$[.68]$} \\
& $1.416^{*}$ & $3.444^{* * *}$ & $2.438^{* * *}$ & $4.562^{* * *}$ \\
& $(0.562)$ & $(0.527)$ & $(0.651)$ & $(0.662)$ \\
Mediter*YSM 6-9 years & {$[-.22]$} & {$[.54]$} & {$[-.25]$} & {$[.57]$} \\
& $0.962^{* *}$ & $2.480^{* * *}$ & $1.309 * *$ & $2.532^{* * *}$ \\
Mediter*YSM 10-15 years & $(0.306)$ & $(0.283)$ & $(0.453)$ & $(0.468)$ \\
& {$[-.16]$} & {$[.44]$} & {$[-.12]$} & {$[.38]$} \\
Mediter*YSM $>15$ years & $0.827 * * *$ & $2.171^{* * *}$ & $0.545 *$ & $1.494 * * *$ \\
& $(0.187)$ & $(0.173)$ & $(0.253)$ & $(0.258)$ \\
& {$[-.14]$} & {$[.40]$} & {$[-.09]$} & {$[.27]$} \\
Carib*YSM $<3$ years & $0.708^{* * *}$ & $2.060^{* * *}$ & 0.118 & $0.862 * * *$ \\
& $(0.120)$ & $(0.110)$ & $(0.183)$ & $(0.184)$ \\
& {$[-.14]$} & {$[.39]$} & {$[-.08]$} & {$[.18]$} \\
Carib*YSM 3-5 years & 0.583 & $1.702^{* *}$ & 0.828 & 1.912 \\
& $(0.709)$ & $(0.642)$ & $(1.062)$ & $(1.073)$ \\
& {$[-.11]$} & {$[.33]$} & {$[-.10]$} & {$[.32]$} \\
Carib*YSM 6-9 years & -0.280 & $1.189^{* * *}$ & $-0.724^{*}$ & 0.671 \\
& $(0.331)$ & $(0.288)$ & $(0.364)$ & $(0.352)$ \\
& {$[-.19]$} & {$[.32]$} & {$[-.22]$} & {$[.23]$} \\
& 0.095 & $0.962^{* * *}$ & -0.092 & $0.716^{* *}$ \\
& $(0.235)$ & $(0.229)$ & $(0.268)$ & $(0.278)$ \\
& {$[-.10]$} & {$[.22]$} & {$[-.11]$} & {$[.17]$} \\
\hline
\end{tabular}




\begin{tabular}{|c|c|c|c|c|}
\hline Carib*YSM 10-15 years & $\begin{array}{l}0.181 \\
(0.166) \\
{[-.09]}\end{array}$ & $\begin{array}{l}1.049 * * * \\
(0.164) \\
{[.23]}\end{array}$ & $\begin{array}{l}-0.007 \\
(0.213) \\
{[-.09]}\end{array}$ & $\begin{array}{l}0.753 * * * \\
(0.223) \\
{[.17]}\end{array}$ \\
\hline \multirow[t]{3}{*}{ Carib*YSM >15 years } & 0.135 & $1.014^{* * *}$ & -0.310 & 0.392 \\
\hline & $(0.126)$ & $(0.124)$ & $(0.194)$ & $(0.202)$ \\
\hline & {$[-.10]$} & {$[.22]$} & {$[-.11]$} & {$[.12]$} \\
\hline \multirow[t]{3}{*}{ East*YSM $<3$ years } & $2.193^{*}$ & $2.970 * *$ & $2.915^{*}$ & $4.023 * * *$ \\
\hline & (1.063) & $(1.066)$ & $(1.143)$ & (1.188) \\
\hline & {$[-.01]$} & [.33] & {$[-.08]$} & [.39] \\
\hline \multirow[t]{3}{*}{ East*YSM 3-5 years } & 0.289 & $0.960 * * *$ & $1.427 * * *$ & $2.347 * * *$ \\
\hline & $(0.318)$ & $(0.289)$ & $(0.376)$ & $(0.353)$ \\
\hline & {$[-.06]$} & {$[.19]$} & {$[-.05]$} & {$[.31]$} \\
\hline \multirow[t]{3}{*}{ East*YSM 6-9 years } & 0.199 & $0.984 * * *$ & $0.700^{*}$ & $1.667 * * *$ \\
\hline & $(0.233)$ & $(0.215)$ & $(0.316)$ & $(0.327)$ \\
\hline & {$[-.08]$} & {$[.21]$} & {$[-.09]$} & {$[.28]$} \\
\hline \multirow[t]{3}{*}{ East*YSM 10-15 years } & $0.504 * *$ & $1.191^{* * *}$ & $0.714^{* * *}$ & $1.620 * * *$ \\
\hline & $(0.159)$ & $(0.157)$ & $(0.209)$ & $(0.220)$ \\
\hline & {$[-.05]$} & {$[.21]$} & {$[-.07]$} & {$[.27]$} \\
\hline \multirow[t]{3}{*}{ East*YSM >15 years } & $0.505^{*}$ & $0.929 * * *$ & 0.401 & $0.963 * *$ \\
\hline & $(0.215)$ & $(0.226)$ & $(0.282)$ & $(0.319)$ \\
\hline & {$[-.01]$} & {$[.15]$} & {$[-.03]$} & [.16] \\
\hline \multirow[t]{3}{*}{ Refugee*YSM < 3 years } & -0.188 & 38.754 & -7.043 & 37.220 \\
\hline & $(0.642)$ & . & $(0.000)$ & \\
\hline & {$[-.35]$} & {$[.70]$} & {$[-.41]$} & {$[.74]$} \\
\hline \multirow[t]{3}{*}{ Refugee*YSM 3-5 years } & 0.333 & $1.337 * *$ & $1.803^{* *}$ & $2.767 * * *$ \\
\hline & $(0.503)$ & $(0.474)$ & $(0.692)$ & $(0.741)$ \\
\hline & {$[-.10]$} & {$[.28]$} & {$[-.05]$} & {$[.34]$} \\
\hline \multirow[t]{3}{*}{ Refugee*YSM 6-9 years } & 0.586 & $1.918 * * *$ & $1.616^{* * *}$ & $3.164 * * *$ \\
\hline & $(0.301)$ & $(0.274)$ & $(0.405)$ & $(0.402)$ \\
\hline & {$[-.14]$} & {$[.38]$} & {$[-.17]$} & {$[.46]$} \\
\hline \multirow[t]{3}{*}{ Refugee*YSM 10-15 years } & 0.251 & $1.251 * * *$ & $1.027 *$ & $2.288 * * *$ \\
\hline & $(0.268)$ & $(0.249)$ & $(0.420)$ & $(0.434)$ \\
\hline & {$[-.11]$} & {$[.27]$} & {$[-.13]$} & {$[.38]$} \\
\hline \multirow[t]{3}{*}{ Refugee*YSM >15 years } & -0.216 & -0.143 & 0.201 & 0.774 \\
\hline & $(0.414)$ & $(0.497)$ & $(0.364)$ & $(0.449)$ \\
\hline & {$[-.03]$} & {$[-.01]$} & {$[-.05]$} & [.15] \\
\hline \multirow[t]{3}{*}{ West*YSM $<3$ years } & $-0.716^{* *}$ & 0.042 & 0.216 & $1.444 * * *$ \\
\hline & $(0.248)$ & $(0.223)$ & $(0.348)$ & $(0.312)$ \\
\hline & {$[-.15]$} & {$[.08]$} & {$[-.15]$} & {$[.31]$} \\
\hline \multirow[t]{3}{*}{ West*YSM 3-5 years } & $-0.514^{* *}$ & 0.183 & 0.025 & $1.040 * * *$ \\
\hline & $(0.172)$ & $(0.156)$ & $(0.278)$ & $(0.274)$ \\
\hline & {$[-.12]$} & [.09] & {$[-.13]$} & {$[.24]$} \\
\hline \multirow[t]{3}{*}{ West*YSM 6-9 years } & $-0.463 * * *$ & -0.075 & -0.135 & $0.583 * *$ \\
\hline & $(0.138)$ & $(0.146)$ & $(0.204)$ & $(0.214)$ \\
\hline & {$[-.09]$} & {$[.03]$} & {$[-.10]$} & {$[.14]$} \\
\hline \multirow[t]{3}{*}{ West*YSM 10-15 years } & $-0.389 * * *$ & 0.022 & -0.254 & $0.384 *$ \\
\hline & $(0.116)$ & $(0.117)$ & $(0.180)$ & $(0.194)$ \\
\hline & {$[-.08]$} & {$[.04]$} & {$[-.10]$} & {$[.11]$} \\
\hline \multirow[t]{2}{*}{ West*YSM < 15 years } & $-0.267 * *$ & $0.388 * * *$ & $-0.545^{* *}$ & 0.214 \\
\hline & $(0.091)$ & $(0.087)$ & $(0.190)$ & $(0.197)$ \\
\hline
\end{tabular}




\begin{tabular}{|c|c|c|c|c|}
\hline & {$[-.10]$} & [.11] & {$[-.14]$} & {$[.10]$} \\
\hline \multirow[t]{2}{*}{ Edu-YSM } & & & 0.001 & $0.001 * *$ \\
\hline & & & $(0.000)$ & $(0.000)$ \\
\hline \multirow[t]{2}{*}{ Edu-mavo } & & & $-0.642 * * *$ & $-1.202 * * *$ \\
\hline & & & (0.069) & $(0.063)$ \\
\hline \multirow[t]{2}{*}{ Edu-vbo } & & & 0.064 & $-0.446^{* * *}$ \\
\hline & & & $(0.067)$ & $(0.062)$ \\
\hline \multirow[t]{2}{*}{ Edu-havo } & & & $-0.838 * * *$ & $-2.722 * * *$ \\
\hline & & & $(0.064)$ & $(0.060)$ \\
\hline \multirow[t]{2}{*}{ Edu-mbo } & & & $-0.251 * * *$ & $-2.571 * * *$ \\
\hline & & & $(0.061)$ & $(0.057)$ \\
\hline \multirow[t]{2}{*}{ Edu-hbo } & & & $-2.725 * * *$ & $-5.414 * * *$ \\
\hline & & & $(0.062)$ & $(0.063)$ \\
\hline \multirow[t]{2}{*}{ Edu-wo } & & & $-3.594 * * *$ & $-6.134 * * *$ \\
\hline & & & $(0.067)$ & $(0.077)$ \\
\hline \multirow[t]{2}{*}{ Woman } & $0.179 * * *$ & $0.291^{* * *}$ & $0.300 * * *$ & $0.520 * * *$ \\
\hline & $(0.014)$ & $(0.015)$ & $(0.016)$ & $(0.019)$ \\
\hline \multirow[t]{2}{*}{ Constant } & $2.014^{* * *}$ & $6.758 * * *$ & $3.459 * * *$ & $8.529 * * *$ \\
\hline & $(0.077)$ & $(0.071)$ & $(0.121)$ & $(0.123)$ \\
\hline Pseudo R2 & 0.06 & & 0.28 & \\
\hline $\mathrm{N}$ & 128062 & & 128036 & \\
\hline
\end{tabular}

The models estimated also include controls for quadratic age and marital status, naturalization, and 3 control variables for the number of children between 0 and 5 , and between 6 and 11 years.

Figure 2. Occupational adjustment profile in Unskilled Jobs by immigrant group (marginal effects from table 4)
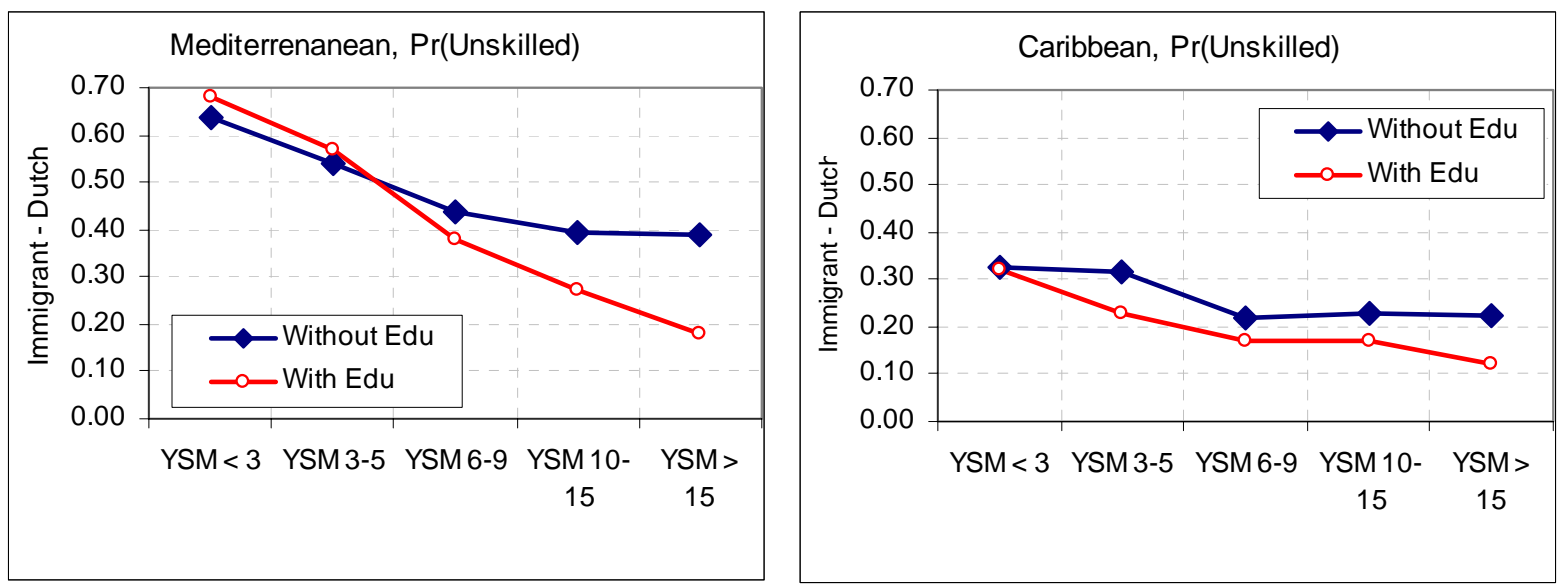

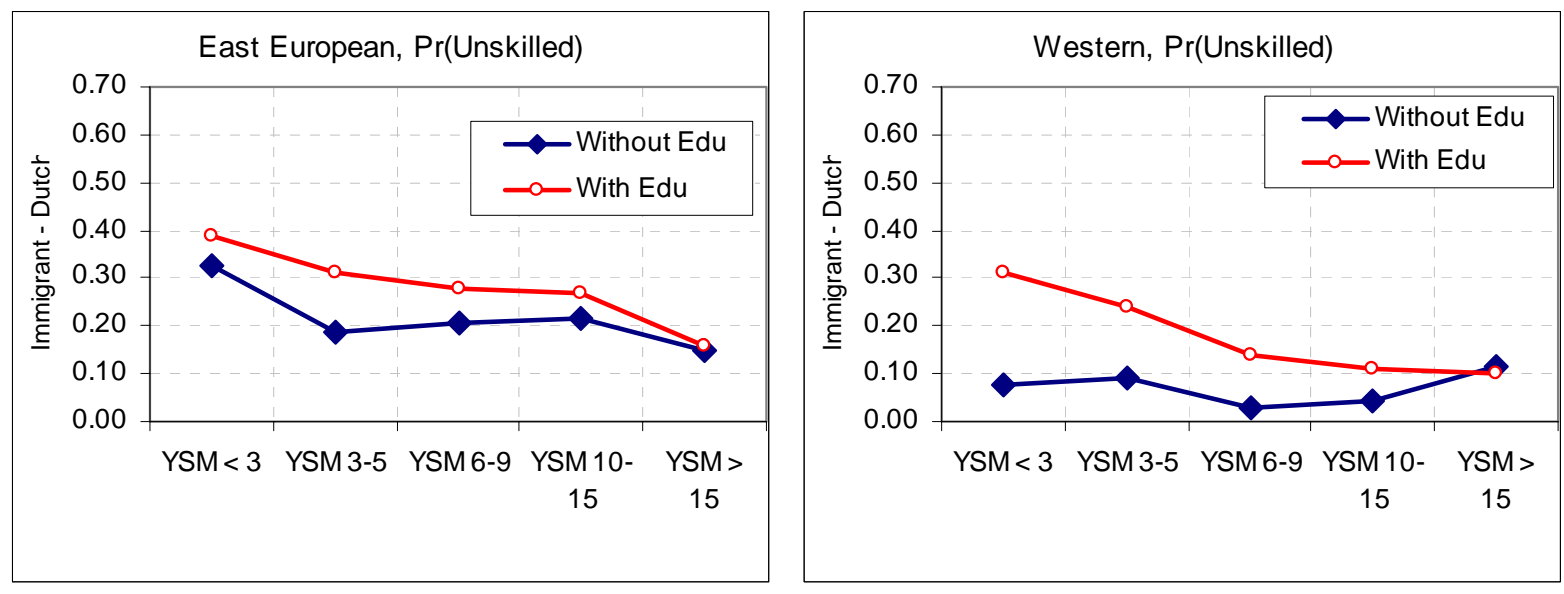

\subsection{Adjustment across education levels}

To illustrate the educational composition of unskilled and intermediate jobs across immigrant groups, we predicted the probabilities for the YSM intervals by education levels per group. These probabilities reflect the adjustment patterns of immigrants with a low, medium or higher level of education. In the face of the high correlation between occupational attainment and education, we expected that less well-educated employees would mostly work in unskilled jobs, medium educated employees in intermediate jobs, and the highly educated in professional jobs, as indicated by the distribution of Dutch employees. Deviations from these patterns roughly reflect the difficulty of skill transferability. It is immediately apparent that almost 82 percent of highly-educated Mediterranean immigrants are employed in unskilled jobs in the first two years of their stay on arrival, 7 percent in intermediate jobs, and only 11 percent in the expected level. With the rise of YSM, medium and highly-educated Mediterranean immigrants in particular have moved to highly-qualified jobs. As the duration of residence exceeds 15 years, only 9 percent of highly-educated Mediterranean immigrants are employed in unskilled jobs and almost 18 percent in intermediate jobs. The other most disadvantaged group is East European immigrants: almost half the highly educated are employed in unskilled jobs in the first years of residence. This percentage declines to 9 for immigrants who have stayed for more than 15 years. Highly-educated immigrants from Caribbean and Western countries have relatively better starting positions and end up very close to their Dutch counterparts. These figures make it clear that all immigrants experience a lower degree of skill transferability to be able to practice occupations associated with their educational level but this margin differs substantially across the groups of immigrants.

Table 5. Predicted probabilities of Unskilled and Intermediate jobs by immigrant group, YSM interval, and education level. These predictions were obtained from the extended multinomial logit model with education presented in table 4 


\begin{tabular}{|c|c|c|c|c|c|c|c|}
\hline & & \multicolumn{3}{|c|}{ Unskilled Occupation } & \multicolumn{3}{|c|}{ Intermediate Occupation } \\
\hline & & Low Edu & Med-Edu & High-Edu & Low Edu & Med-Edu & High-Edu \\
\hline & Native Dutch & 0.671 & 0.241 & 0.041 & 0.241 & 0.536 & 0.146 \\
\hline \multirow[t]{5}{*}{ Mediter. } & . YSM $<3$ years & 0.991 & 0.942 & 0.817 & 0.008 & 0.054 & 0.071 \\
\hline & YSM 3-5 years & 0.961 & 0.793 & 0.571 & 0.038 & 0.199 & 0.231 \\
\hline & YSM 6-9 years & 0.903 & 0.581 & 0.225 & 0.090 & 0.372 & 0.226 \\
\hline & YSM 10-15 years & 0.861 & 0.480 & 0.130 & 0.118 & 0.411 & 0.197 \\
\hline & YSM >15 years & 0.788 & 0.364 & 0.094 & 0.170 & 0.475 & 0.197 \\
\hline \multirow[t]{5}{*}{ Carib } & YSM $<3$ years & 0.918 & 0.599 & 0.217 & 0.071 & 0.346 & 0.229 \\
\hline & YSM 3-5 years & 0.866 & 0.485 & 0.116 & 0.086 & 0.298 & 0.084 \\
\hline & YSM 6-9 years & 0.794 & 0.393 & 0.105 & 0.155 & 0.439 & 0.176 \\
\hline & YSM 10-15 years & 0.788 & 0.358 & 0.082 & 0.167 & 0.479 & 0.182 \\
\hline & YSM >15 years & 0.714 & 0.288 & 0.070 & 0.206 & 0.506 & 0.173 \\
\hline \multirow[t]{5}{*}{ East } & YSM $<3$ years & 0.923 & 0.587 & 0.483 & 0.076 & 0.404 & 0.349 \\
\hline & YSM 3-5 years & 0.919 & 0.555 & 0.204 & 0.077 & 0.405 & 0.247 \\
\hline & YSM 6-9 years & 0.929 & 0.520 & 0.132 & 0.064 & 0.396 & 0.177 \\
\hline & YSM $10-5$ years & 0.879 & 0.469 & 0.145 & 0.106 & 0.439 & 0.183 \\
\hline & YSM >15 years & 0.728 & 0.313 & 0.089 & 0.229 & 0.557 & 0.220 \\
\hline \multirow[t]{5}{*}{ Refugee } & YSM $<3$ years & 0.000 & 0.000 & & 0.000 & 0.000 & \\
\hline & YSM 3-5 years & 0.924 & 0.599 & 0.204 & 0.073 & 0.376 & 0.287 \\
\hline & YSM 6-9 years & 0.945 & 0.662 & 0.277 & 0.052 & 0.307 & 0.236 \\
\hline & YSM 10-15 years & 0.904 & 0.570 & 0.187 & 0.087 & 0.369 & 0.213 \\
\hline & YSM >15 years & 0.687 & 0.289 & 0.058 & 0.261 & 0.543 & 0.162 \\
\hline \multirow[t]{5}{*}{ West } & YSM $<3$ years & 0.849 & 0.601 & 0.151 & 0.108 & 0.299 & 0.113 \\
\hline & YSM 3-5 years & 0.882 & 0.499 & 0.084 & 0.092 & 0.358 & 0.094 \\
\hline & YSM 6-9 years & 0.823 & 0.351 & 0.054 & 0.132 & 0.446 & 0.098 \\
\hline & YSM 10-15 years & 0.793 & 0.346 & 0.048 & 0.148 & 0.436 & 0.097 \\
\hline & YSM <15 years & 0.740 & 0.326 & 0.055 & 0.176 & 0.425 & 0.103 \\
\hline
\end{tabular}

\section{Conclusions and Discussion}

Immigration literature has used earnings and employment outcomes to analyse the adjustment of immigrants in the host-country labour-markets. This paper extends this literature by examining the rate of adjustment of immigrants in occupational structures in the Netherlands using three different measures of occupational attainment. The analysis shows that highlyeducated immigrants start with low-skilled jobs on arrival. Among immigrant groups, the starting position of Mediterranean immigrant is the lowest. They are followed by East European immigrants, and at a distance by Caribbean and western immigrants. This rank order reflects at the same time the rate of adjustment for these groups, which confirms the prediction of the theory of immigrant occupational mobility. Mediterranean immigrants experience a substantial initial disadvantage that is associated with a low level of skill transferability. This large gap possibly permits investment in host-country-specific capital so that their position improves considerably as they reside longer in the Netherlands. At the other extreme, the initial disadvantage of Western immigrants is relatively small and they catch up with their Dutch counterpart after 15 years. Also the initial dip of Caribbean immigrants is relatively small, but they do not catch up with the Dutch although they approach them. The relatively less-disadvantaged starting position of these immigrants is probably related to their 
favourable but unmeasured qualifications associated with socio-cultural distance from Dutch society, since the estimates control adequately for demographic and household characteristics and education level. These favourable qualifications (which are often referred to as 'hostcountry-specific capital endowment') possibly stem from different sources for Caribbean and Western immigrants. Many Caribbean immigrants speak Dutch and are familiar with mainstream cultural norms and values because of their colonial background. In addition, they may have the legal rights that are necessary to access additional sources to facilitate their integration into the Dutch labour market. On the other hand, western immigrants come to the Netherlands as labour migrants and they may benefit from a smaller linguistic and cultural distance from Dutch society. The adjustment pattern of refugee migrants does not reflect a consistent improvement, possibly owing to the changing skill composition of refugee inflows from Iran, Iraq, and Afghanistan. The group-specific adjustment patterns identified are consistent across the alternative measures of occupational attainment.

The analysis indicates that labour market adjustment of immigrants runs through interoccupational job mobility, rather than intra-occupational job mobility. Immigrants' skills are drastically undervalued in the first years of residence so that immigrants are employed in much less skilled jobs, given their skill endowment, compared with the Dutch. As the duration of residence increases and immigrants accumulate more host country specific capital, they move to higher skilled jobs. This result suggests that immigrants' earnings gap is likely to be driven largely by their lower occupational attainment. They face significant difficulties after immigration to have access to jobs fitting their qualifications that they acquired in the home country.The result can also imply that high unemployment among immigrants is less likely to be an outcome of immigrants' selective attitude with respect to the skill level of jobs offered. Obviously, most immigrants accept much lower qualified jobs with respect to their productive skills. An implication of this study may be an expected high efficiency of policies which aim to improve immigrants' access to jobs in higher levels of the occupational distribution. Additional training programmes for specific occupations may help to decline the initial gap and accelerate adjustment process. 


\section{References}

Aldashev, A, J. Gernandt and S.L. Thomsen (2009). Language usage, participation, employment and earnings - evidence for foreigners in west-Germany with multiple sources of selection. Labour Economics 16, pp. 330-341.

Akresh, I. R. (2006). Occupational mobility among legal immigrants to the United States. International Migration Review, 40, 4, 854-884.

Bevelander, P. \& J. Veenman (2004). Variation in Perspective: The Employment Success of Ethnic Minority Males in the Netherlands, 1988-2002. International Migration, 42, 4, pp. 35-64

Bevelander, P., \& S. Groeneveld (2006) Patterns of transition. Female native and ethnic minority employment patterns in the Dutch labor market, 1991 and 2002. Journal of Ethnic and Migration Studies, 32(5), pp. 785-807.

Bijwaard, G.E. (2010). Immigrant migration dynamics model for The Netherlands. Journal of Population Economics, 23 (4), pp. 1213-1247.

Borjas, G. J. (1995). Assimilation and changes in cohort quality revisited: what happened to immigrant earnings in the 1980s? Journal of Labour Economics, 13, 2, pp. 201-245

Bourdieu, P. (1986). The forms of capital. In J. Richardson (Ed.) Handbook of Theory and Research for the Sociology of Education, New York, Greenwood, pp. 241-258.

Chiswick, B.R. (1978). The Effect of Americanization on the Earnings of Foreign-Born Men, Journal of Political Economy, pp. 897-922

Chiswick, B.R, Cohen, Y. and Zach, T. (1997). The Labor Market Status of Immigrants: Effects of the Unemployment Rate at Arrival and Duration of Residence. Industrial and Labor Relations Review, 50, pp. 289-303.

Chiswick, B.R. and Miller, P.W. (1998) English language fluency among immigrants in the United States. Research in Labor Economics 17, pp. 151-200

Chiswick, B. R., Lee, Y. L. and Miller, P. W. (2005). A Longitudinal Analysis of Immigrant Occupational Mobility: A Test of the Immigrant Assimilation Hypothesis, International Migration Review, 39, 2, pp. 332-353

Chiswick, B.R. and Miller, P.W. (2008a). Why is the payoff to schooling smaller for immigrants? Labour Economics, 15, 6, pp. 1317-1340.

Chiswick, B.R. and Miller, P.W. (2008b). Occupational attainment and immigrant economic progress in Australia. Economic Record, 84, pp. 845-856.

Chiswick, B.R. and Miller, P.W. (2009). The international transferability of immigrant's human capital. Economics of Education Review, 28, 2, pp. 162-169.

Duleep, H.O. and Regets, M.C. (1999). Immigrants and Human-Capital Investment. American Economic Review 89,1, pp. 86-90.

Evans, G. (1992). Testing the validity of Goldthorpe class schema”, European Sociological Review, 8, 3, pp. 211-232

Friedberg, R.M. (2000). You Can't Take It With You? Immigrant Assimilation and the Portability of Human Capital. Journal of Labor Economics 18, pp. 221-51.

Ganzeboom, H.B.G. and Treiman, D.J. (1996). Internationally Comparable Measures of Occupational Status for the 1988 International Standard Classification of Occupations. Social Science Research, 25, pp. 201-239

Groshen, E. (1991). Sources of Intra-Industry Wage Dispersion: How Much Do Employers Matter? Quarterly Journal of Economics, vol. 106, 3, 869-884

Hartog, J. and A. Zorlu (2009). How Important is Homeland Education for Refugees' Economic Position in the Netherlands?, Journal of Population Economics, 22, pp. 219-246 
Kanas, A and van Tubergen, F. (2009). The impact of origin and host country schooling on the economic performance of immigrants. Social Forces, 88 (2), 893-915

Kambourov, G. and Manovskii, I. (2009). Occupational Mobility and Wage Inequality. Review of Economic Studies, 76, 2, 731-759.

Orrenius, P.M. and M. Zavodny (2009) Do Immigrants Work in Riskier Jobs? Demography, 46, 3, 535-551

Rooth, D.-O. and Ekberg, J. ( 2006) Occupational mobility for immigrants in Sweden. International Migration, 44, 57-77

Rosholm, M., Scott, K. and Husted, L. (2006), The Times They Are A-Changin: Declining Immigrant Employment Opportunities in Scandinavia. International Migration Review, 40, 2, 318-347

Van de Ven, W.P. and B. van Praag (1981). The demand for deductibles in private health insurance. Journal of Econometrics 17, 229-252

Van Tubergen F. and Van de Werfhorst, H. (2007). Postimmigration Investments in Education: A Study of Immigrants in the Netherlands. Demography 44, 4, 883-898

Zorlu, A. and J. Hartog (2008). Employment assimilation of immigrants in the Netherlands: catching up and the irrelevance of education. IZA discussion paper no 3534. 